\title{
Hevosyrittäjänä vuonna 2014
}

Terhi Thuneberg ${ }^{l)}$ Sirpa Pussinen ${ }^{2)}$, ja Jukka Korhonen ${ }^{2)}$, Hämeen ammattikorkeakoulu, ${ }^{1)}$ Mustialantie 105, 31310 Mustiala ja ${ }^{2)}$ Uudenmaankatu 22, $05800 \mathrm{Hy-}$ vinkää, etunimi.sukunimi@hamk.fi

\section{Tiivistelmä}

Hevostalous on kasvanut 1990- ja 2000-luvuilla. Harrastajien, yrittäjien ja hevosten määrä on yhä kasvussa. Hämeen ammattikorkeakoulu toteutti keväällä 2009 hevosalan yrittäjille kyselyn, jolla kartoitettiin yrittäjien näkemyksiä lähitulevaisuuden kysyntätilanteesta ja kannattavuudesta. Hevosyrittäjyyskyselyn toteutti puhelinhaastatteluna Suomen Gallup Elintarviketieto Oy, ja se tavoitti valtakunnallisesti 295 hevosyrittäjää.

"Keskimääräinen" hevosyrittäjä harjoitti tallitoimintaa yritystoimintana kuudentoista vuoden kokemuksella ja oli iältään 49-vuotias. Yrittäjistä enemmistöllä hevostoiminta oli maatilatalouden tuloverolain mukaista toimintaa ja yritystoiminta tapahtui maatilan yhteydessä. Yli puolella (63\%:1la) yrittäjistä oli yli 10 hevos- tai ponipaikkaa keskiarvon ollessa 18. Suurin osa hevosista oli omia hevosia - vieraita hoitohevosia oli keskimäärin viisi. Hevos- ja ponipaikkojen määrä tullee viiden vuoden aikajänteellä pysymään suurin piirtein samana.

Pääasiallisista toimintamuodoista viisi yleisintä olivat hevoskasvatus (omaan käyttöön ja/tai myyntiin) (35\%), ratsastustuntitoiminta (21\%), omien hevosten ravivalmennus (13\%), karsinapaikkojen vuokraus $(9 \%)$ sekä oriasematoiminta $(7 \%)$. Pääasiallisen toiminnan ohessa harjoitettiin yleisimmin hevoskasvatusta ja karsinapaikkojen vuokrausta.

Vaikka kysely suoritettiin taloustaantuman aikana, hevosyrittäjät näkivät tulevaisuuden pääosin myönteisenä. Positiivisuus näkyi niin laajentamisaikeiden kuin kysyntätilanteen arvioinnissa. Lähes $75 \%$ vastasi toiminnan laajenevan tai pysyvän ennallaan. Useimmiten toiminnan laajentamisen taustalla oli yrityksen strateginen valinta. Kannattavuusnäkymiä pidettiin melko hyvinä: vastaushetkellä 58\% yrittäjistä koki kannattavuuden olevan vähintään tyydyttävällä tasolla, ja viiden vuoden päästä jopa $70 \%$ näki kannattavuuden olevan vähintään tyydyttävällä tasolla. Vastaajat uskoivat enemmän kysynnän parantumiseen kuin heikentymiseen. Kysynnän paranemiseen uskottiin etenkin ratsastustuntitoiminnassa sekä ratsuhevosten koulutuksessa ja ratsastusvalmennuksessa.

Laajentamissuunnitelmien vastapainona näkyi erityisesti hevoskasvatuksessa toimintaa vähentävien, lopettavien tai harrastukseen siirtyvien melko suuri osuus (34\%). Kasvatustoiminnan haasteena on yritystoimintaa harjoittavien korkea keski-ikä, 52 vuotta. Vähentämisen syitä olivat sukupolvenvaihdokset ja eläkkeelle siirtyminen, mutta myös työn raskaus ja terveyssyyt. Työn organisointiin, tekniikan hyödyntämiseen, lomituspalveluihin ja muihin jaksamista parantaviin toimenpiteisiin tulisikin hevosalalla panostaa.

Kyselyn tulokset osoittivat hevosalan positiivisen hengen ja vankan uskon tulevaisuuteen. Hevosalan kasvu ei ole kuitenkaan itsestäänselvyys; toimenpiteitä vakaan tilanteen ylläpitämiseksi tarvitaan. Toimialan seuranta on tärkeää. Tietoa tarvitaan hevosalaa koskevien päätösten ja rahoitusten tueksi, jotta ala kehittyy ja säilyy yhtenä maaseudun kasvavana alana.

Asiasanat: Maaseutuyrittäjyys, hevostalous 


\title{
Johdanto
}

Hevostalous on kasvanut viimeisinä vuosikymmeninä tasaiseen tahtiin. Hevosten määrän kasvu 2000luvulla on ollut yli 1000 hevosta vuodessa. Vuonna 2009 rikkoutui 70000 rekisteröidyn hevosen raja. Uusia harrastajia virtaa niin ratsastuksen kuin raviurheilun pariin; ratsastuksen harrastajia on 150000 ja raviradoilla käy vuosittain yleisöä liki 800 000. Hevostalouden keskiössä ovat hevoset ja niiden kasvattajat, mutta lisäksi tarvitaan yrittäjiä, jotka tarjoavat harrastajille puitteet ja palvelut. Laadukkaille palveluille on kysyntää, ja uusia yrityksiä on syntynyt hevosalalle jatkuvasti.

Hämeen ammattikorkeakoulu (HAMK) toteutti keväällä 2009 kyselyn hevosalan yrittäjille. Kyselyllä kartoitettiin yrittäjien näkemyksiä lähitulevaisuuden kysynnästä ja kannattavuudesta sekä yritystoiminnan muutoksista. Taustalla vaikutti Laurea ammattikorkeakoulun toimesta vuonna 2005 tehty barometri, joka selvitti hevosalan investointeja ja yrittäjyyden muutoksia.

\begin{abstract}
Aineisto ja menetelmät
Hevosyrittäjyys-kyselyn toteutti Suomen Gallup Elintarviketieto Oy. Kysely tehtiin informoituna kyselynä ja puhelinhaastatteluna. Osoitelähteenä käytettiin Suomen Gallup Elintarviketieto Oy:n vuonna 2005 toteuttamaan ja Laurea-ammattikorkeakoulun tilaamaan kyselyyn vastanneiden osoitetietoja. Alun perin otannan ja osoitetietojen lähteinä olivat Suomen Hippos ry:n hevosenomistajarekisterin kolmen tai useamman hevosen omistajat ja Suomen Ratsastajainliitto ry:n jäsentallien tiedot. Kysely postitettiin kirjeitse etukäteen tutustumista varten 680 hevosenomistajalle, joista tavoitettiin puhelimitse 432. Puhelinhaastatelluista 295 harjoitti yritystoimintaa, 46 oli lopettanut yritystoimintansa vuoden 2005 kyselyn jälkeen ja 91 harjoitti harrastusmuotoista toimintaa. Koska kyselyyn tavoitettiin samat yrittäjät (295 kpl), jotka olivat vastanneet vuoden 2005 kyselyyn, tulokset ovat vertailukelpoisia ja alalla tapahtuneita muutoksia päästään seuraamaan luotettavasti. Kyselyn otos edustaa noin 10\% yritystoimintaa harjoittavista talleista, joita arvioitiin vuonna 2005 olevan Suomessa noin 3000 (Pussinen ym. 2007).

Kysely sisälsi 23 kysymystä, joista osa oli monivalintakysymyksiä, osa strukturoituja ja avoimia kysymyksiä, ja osa asteikkoihin perustuvia kysymyksiä. Kysymysten laadinnassa olivat mukana hevosalan keskeisten organisaatioiden edustajat, koska kysymyksillä haluttiin saada vastauksia akuutteihin selvitystarpeisiin. Aineisto käsiteltiin SPSS Statistics 17.0 - tilasto-ohjelmalla.
\end{abstract}

\section{Tulokset ja tulosten tarkastelu}

Hevosalan yrittäjyydessä on tyypillistä siirtyä vähitellen harrastustoiminnasta yrittäjäksi. Yrittäjistä 20\% (59) ilmoittikin harjoittavansa tallitoimintaa sekä harrastuksena että yritystoimintana. Hevosyrittäjyys voi olla elämätapa, jossa taloudelliset tavoitteet eivät aina ole päällimmäisinä. Hevosyrittäjyyden taustalla oli keskimäärin kuudentoista vuoden kokemus (vuodesta 1993) tallitoiminnan harjoittamisesta yritystoimintana sekä yrittäjyyttä edeltänyt viisivuotinen kokemus tallitoiminnasta harrastusmuotoisena. Kolmannes (33\%) oli aloittanut yritystoimintansa 2000-luvulla, 37\% 1990-luvulla ja 22\% 1980-luvulla. Yrittäjistä 8\% pyöritti toimintaansa yli 29 vuoden kokemuksella.

Tallitoimintaa harjoittavan hevosyrittäjän keski-ikä oli 49 vuotta; vain kymmenesosa $(11 \%)$ yrittäjistä oli alle 35-vuotiaita, 46\% kuului ikäryhmään 35-50 vuotta ja 43\% oli yli 50-vuotiaita. Ikäjakauma ei merkittävästi poikkea muista yrittäjistä. Suomen Yrittäjien jäsenkunnasta on 30\% 51-60vuotiaita ja $16 \%$ yli 60-vuotiaita (Suomen Yrittäät 2008), ja viljelijöiden keski-ikä on 50 vuotta (Tike 2009). Hevostoiminta oli maatilatalouden tuloverolain mukaista toimintaa 69\%:lla yrittäjistä, ja yritystoiminta toteutui maatilan yhteydessä tai maatalousyhtymänä 61\%:1la. Maatilakytkentä on siis yhä vahvaa, vaikka maatilojen lukumäärä on koko maassa laskenut. Pussisen ym. (2007) mukaan vuonna 2005 75\% hevosyrittäjistä toimi maatilan yhteydessä. Päätuotantosuuntanaan hevostaloutta harjoittavia maatiloja oli Maa- ja metsätalousministeriön tietopalvelukeskuksen (2008) mukaan 2105 tilaa.

Karsinapaikkoja hevosyrittäjällä oli keskimäärin 18, joista 5 hoitohevosten, ns. vieraiden hevosten, käytössä. Vieraiden hevosille tarjottavien karsinapaikkojen keskiarvoa laski sellaisten tallien suuri määrä $(40 \%)$, joissa oli vain omia hevosia. Yrittäjillä, jotka tarjosivat tallipaikkoja myös vieraille hevosille, oli keskimäärin 22 karsinapaikkaa, joista 8 vieraiden hevosia varten. Tiilikainen (2004) totesi maatilatalouden yritys- ja tulotilastoon kuuluvillaa hevostiloilla olevan keskimäärin 6 hevosta. 
Hevosalan keskimääräistä yrittäjää on vaikea tarkemmin määritellä, koska toimintamuodot eroavat toisistaan merkittävästi. Hevosyrittäjien päätoimintamuodoista kolme yleisintä olivat hevoskasvatus (omaan käyttöön ja/tai myyntiin), ratsastustuntitoiminta ja ravivalmennus (Kuva 1). Ainoastaan $13 \%$ yrittäjistä harjoitti vain yhtä toimintamuotoa - tyypillistä hevosyritykselle on siis päätoimintamuodon ohella harjoitettava muu toiminta.

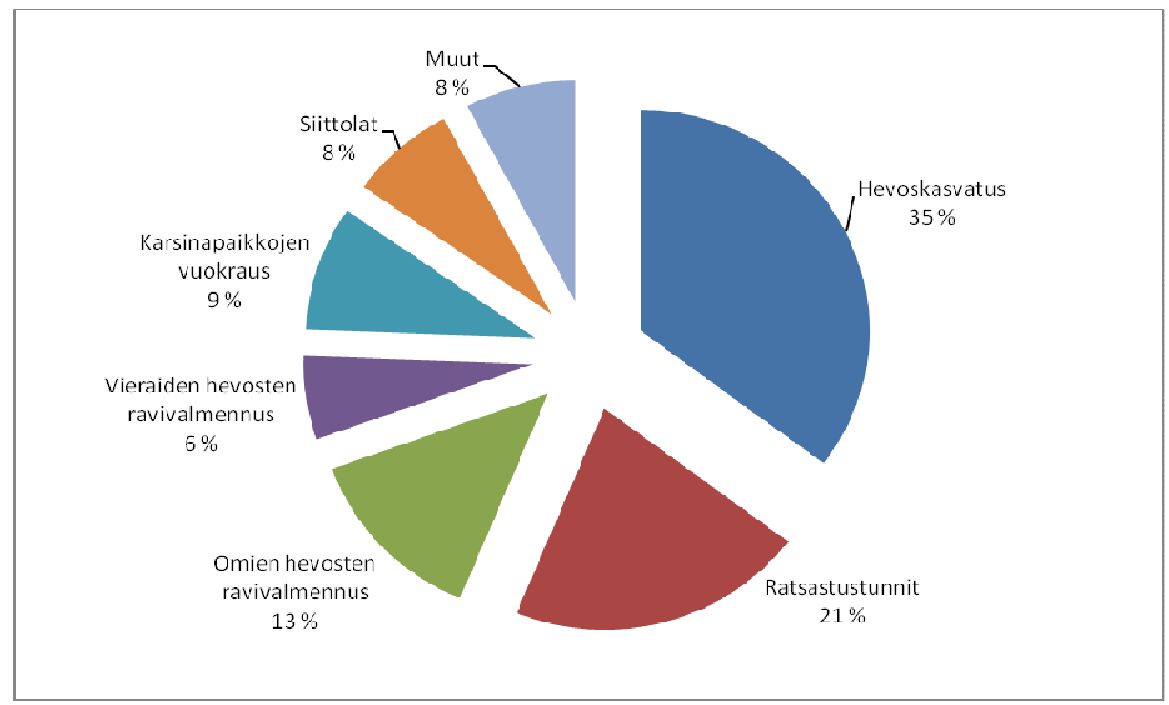

Kuva 1. Kyselyyn vastanneiden hevosyritysten jakautuminen päätoimintamuotoihin.

\section{Hevoskasvatus}

Hevoskasvatusta päätuotantomuotonaan harjoittavia yrittäjiä vastasi kyselyyn 104 kappaletta. Hevoskasvattajalla on vankka kokemus yritystoiminnan pyörittämisestä; keskimäärin toiminta oli aloitettu 16 vuotta sitten ja yrittäjä oli 52-vuotias. Alle 35-vuotiaita oli marginaalinen osuus, eli lyhyellä kasvatuskokemuksella ei helposti ryhdytä yritysmuotoiseksi kasvattajaksi (Kuva 2.). Kasvatustoiminta oli selkeästi maatilakytkentäistä: $81 \%$ toiminnasta tapahtui maatilan yhteydessä tai maatalousyhtymän nimissä. Toimintamuodon yrittäjien ikääntyminen näkyi myös investointien vähyydessä - vain $33 \%$ oli investoinut yli 5 000€:lla toiminnan puitteisiin tai olosuhteisiin vuoden 2005 jälkeen. Liikevaihto hevoskasvatuksen osalta oli keskimäärin $30000 €$, ja 76\%:lla yrittäjistä liikevaihto jäi tämän alle. Karsinapaikkakohtainen liikevaihto oli kasvatustoiminnassa toimintamuodoista alhaisimmillaan (2 500€).

\section{Ratsastustuntitoiminta}

Ratsastustunteja tarjoavia yrittäjiä oli 62 kappaletta. Yrittäjän keski-ikä oli 44 vuotta. Hevos- ja ponipaikkoja ratsastustuntitoiminnan yrittäjällä oli 26, joista 5 vieraita hevosia varten. Yrittäjistä $60 \%$ oli investoinut vuoden 2005 jälkeen yli 5 000€:lla, ja vuoteen 2014 mennessä 29\% aikoo tehdä investointeja. Liikevaihdon keskiarvo oli $135000 €$ mediaanin jäädessä $90000 €$. Yrittäjistä 62\%:lla liikevaihto jäi alle keskiarvon. Suurimmissa yrityksissä liikevaihdot olivat useissa sadoissa tuhansissa euroissa ja karsinapaikkakohtainen liikevaihto 4000 ja $5000 €$ välillä. Vähintään yksi palkattu työntekijä oli joka kolmannella yrittäjällä.

\section{Ravivalmennus}

Ravivalmennuspalvelua harjoittava yrittäjä oli keskimäärin 44-vuotias, ja piti tallissaan 26 hevosta. Liikevaihdon keskiarvo ravivalmentajilla oli $127000 €$ (mediaani $90000 €$ ). Heistä $67 \%$ oli tehnyt vuoden 2005 jälkeen yli $5000 €$ investointeja, ja 39\% aikoo myös viiden vuoden sisällä investoida. Yrittäjällä voi olla useitakin palkattuja työntekijöitä. Sen sijaan omien hevosten ravivalmennus oli suhteellisen pienimuotoista toimintaa, liikevaihdon keskiarvon jäädessä $25000 €$ (mediaani $9000 €$ ). Karsinapaikkakohtainen liikevaihto oli valmennuspalveluita tarjoavilla yrittäjillä samaa suuruusluokkaa mitä ratsastustuntitoimintaa harjoittavilla, kun omia hevosia valmennettaessa se jäi suuruusluokal- 
taan vastaavalle tasolle kuin hevoskasvatuksen kohdalla. Liikevaihdot olivat suhteellisen yhteneväisiä, mitä Liljenstolpe (2009) esitteli eurooppalaisesta hevostaloudesta.

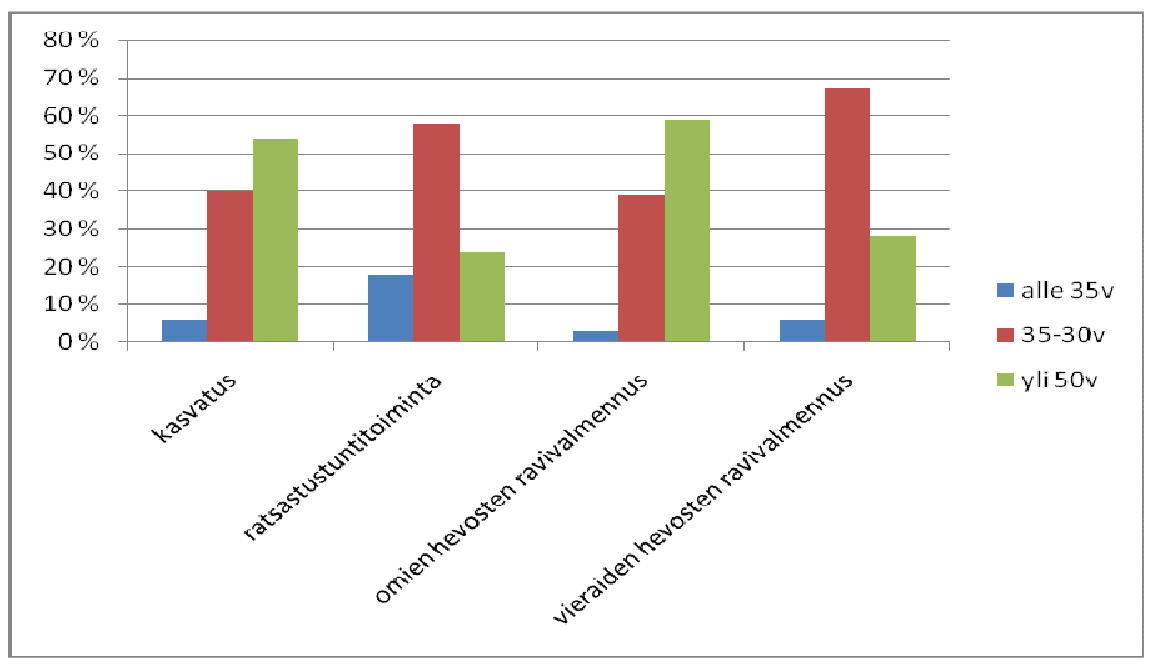

Kuva 2. Yrittäjien jakaantuminen ikäluokkiin toimintamuodoittain.

\section{Osa laajentaa, myös toimintaansa vähentäviä löytyy}

Kyselyllä selvitettiin yrittäjien laajentamisaikeita. Vastaajista viidennes (19\%) oli laajentamassa toimintaansa seuraavan viiden vuoden aikana, kun vuoden 2005 kyselyssä vastaava osuus oli 39\% (Pussinen ym. 2007). Laajentamisinnokkuus ei näytä olleen niin suurta mitä neljä vuotta sitten oli kaavailtu. Tähän osasyynä saattaa olla taloudellinen tilanne, mutta toisaalta uudet yritykset vakiinnuttavat toimintaansa ja panostavat yrityksensä kehittämiseen toisilla tavoin. Yleisin syy laajentamiseen oli yrityksen strateginen valinta, ja erityisesti nuorissa yrittäjissä oli uskoa toiminnan kannattavuuteen. Laajentavat yritykset arvioivat kannattavuuteensa positiivisemmin kuin koko vastaajajoukko. Uusia yrityksiä on syntynyt viime vuosien aikana vähemmän kuin 2000-luvun alkupuolella. Perustamisaikeita on mahdollisesti siirretty heikosta taloudellisesta tilanteesta johtuen.

Toimintaansa selkeästi vähentäviä tai kokonaan harrastukseen siirtyjiä oli 23\%. Yleisimpinä syinä mainittiin työn raskaus ja terveyssyyt. Eläkkeelle siirtyviä tai sukupolvenvaihdosta tekeviä oli noin kolmannes toiminnan kannattamattomuuden ja muiden syiden jääden vähemmistöksi (Kuva 3.).

Ainoastaan 5\% kaikista yrittäjistä harkitsi toiminnan lopettamista. Kyseisiin yrityksiin ei juuri oltu investoitu vuoden 2005 jälkeen, eikä niissä käytetty palkattua työvoimaa. Lopettavista yrityksistä enemmistö ei osannut nimetä edes yrityksensä päätoimintamuotoa - tällaisissa yrityksissä toiminta ei kenties ole kovin tavoitteellista ja suunnitelmallista, aidosti yrittäjämäistä?

Yrityksen kannattavuusnäkymiä puntaroitaessa 58\% vastaajista koki kannattavuuden olevan vähintään tyydyttävällä tasolla, kun viiden vuoden päästä jopa $70 \%$ näki kannattavuuden olevan vähintään tyydyttävällä tasolla. Erittäin heikkona kannattavuuden näki nyt $6 \%$ ja tulevaisuudessa $3 \%$. (Kuva 4.). Kannattavuuden arviointiin ei kyselyssä annettu kriteereitä tai numeerisia arvoja, vaan vastaukset pohjautuvat yrittäjien omaan kokemukseen kannattavuusnäkymistä vastaushetkellä ja lähivuosina aikana. 


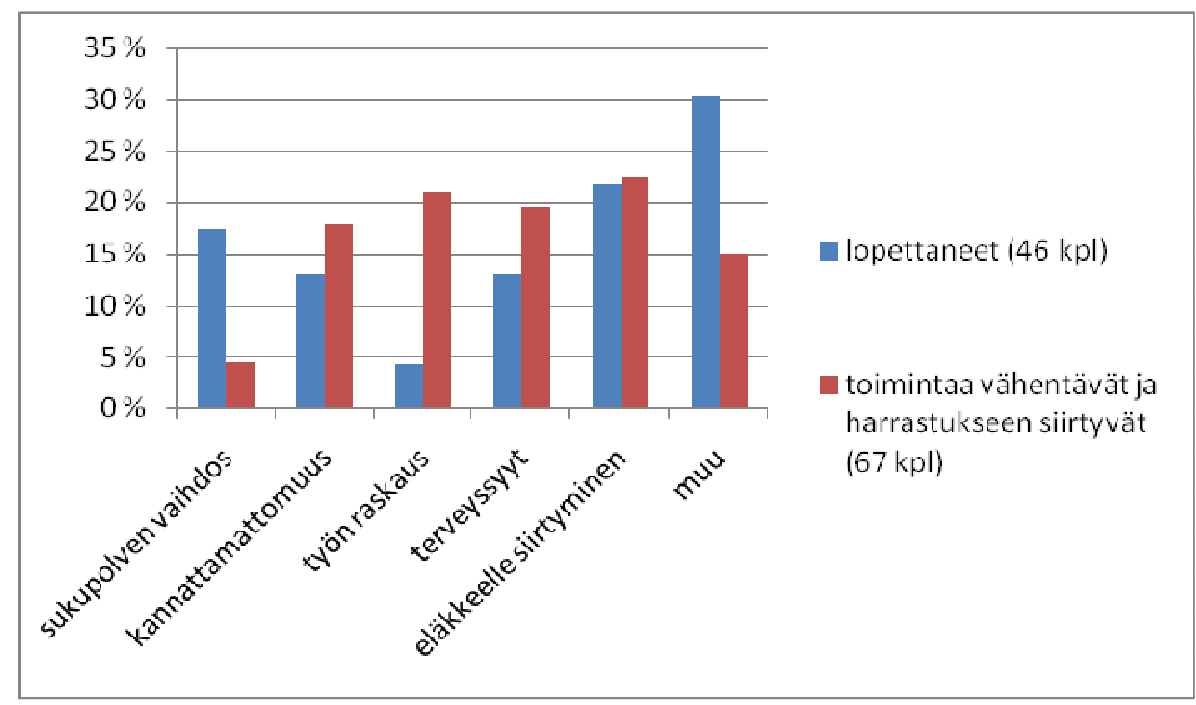

Kuva 3. Syitä yritystoiminnan lopettamiseen ja vähentämiseen, kun tarkastelussa ovat toimintansa vuosina 2005-2009 lopettaneet sekä toiminnan vähentämistä tai harrastukseen siirtymistä vuosien 20092014 aikana suunnittelevat.

Samaten vastaajat uskovat enemmän kysynnän parantumiseen kuin heikentymiseen. Kysynnän paranemiseen uskottiin etenkin ratsastustuntitoiminnassa sekä ratsuhevosten koulutuksessa ja ratsastusvalmennuksessa. Myös vaellusratsastus ja valjakkoajo nähtiin vahvasti kasvavina lajeina kysynnän suhteen, mutta on muistettava, että kyseiset lajit ovat suhteellisen marginaalisia ja vastaajajoukko pieni. Kansallisen hevosmatkailututkimuksen mukaan hevosmatkailu on joko erittäin tai melko kannattavaa liiketoimintaa 76\%:lle hevosmatkailupalveluita tuottaville yrityksille. Hevosmatkailun kasvattamisen investointiaikeita oli kolmanneksella yrittäjistä (Matkailun edistämiskeskus 2009).

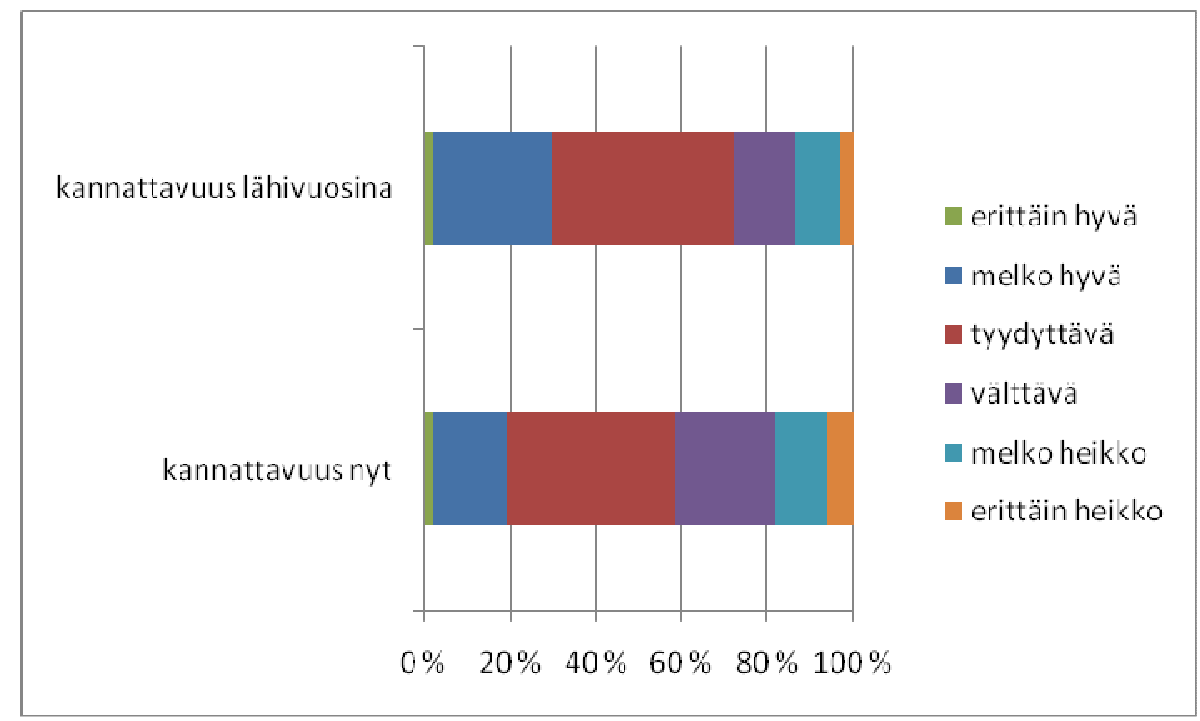

Kuva 4. Vastaajien arvio yrityksensä kannattavuudesta nyt ja viiden vuoden kuluttua.

\section{Johtopäätökset}

Yritysmuotoiset tallit ovat selvästi harrastustalleja suurempia. Kyselyn tavoittamissa talleissa oli keskimäärin 17 karsinapaikkaa ja yrittäjistä 63\%:lla oli yli 10 hevos- tai ponipaikkaa. Heiskasen ym. (2002) mukaan talleissa on keskimäärin 4,3 hevosta ja alle 10 hevosen talleja on $91 \%$ talleista, kun mukaan luetaan myös 1-2 hevosen tallit. Hevosyrittäjyydessä voidaan nähdä kaksi erilaista "urapol- 
kua”: yhtäältä osa yrittäjistä vähentää toimintaansa ja pienentää volyymiä keskittyen hevosiin lähinnä omana harrastuksena, ja toisaalta osa joko laajentaa tai vakiinnuttaa toimintaansa keskittyen johonkin suhteellisen kapea-alaiseen palveluntarjontaan (erikoistuminen).

Hevosyritysten päätoimintamuodoissa ei ole tapahtunut suuria muutoksia. Pussinen ym. (2007) raportoivat havaintojen hyvin samankaltaisista jakaumista päätoimintamuodoittain. Viimeisten vuosien aikana yritykset ovat todennäköisesti profiloituneet vankemmin päätoimintamuotoonsa, koska vuonna $20057 \%$ hevosyrittäjistä harjoitti vain yhtä päätoimintamuotoa vastaavan luvun ollessa nyt $13 \%$. Koska yritykset profiloituvat ja erikoistuvat entistä voimakkaammin, on mielenkiintoista seurata tuleeko hevosyritysten maatilakytkentäisyydessä tapahtumaan muutoksia. Toimintamuodoista hevoskasvatus tapahtuu yleisimmin maatiloilla, ja hevoskasvattajien ikääntymisen myötä tapahtuu vähenemistä. Uusien kasvattajien saamiseen alalle täytyy kiinnittää huomiota, että säilytetään kotimainen kasvatustoiminta vähintään nykyisellä tasolla.

Erityisesti yritystoimintaa vähentäneiden ja toimintansa kokonaan lopettaneiden vastauksista tuli ilmi alan haasteet: työ on raskasta niin fyysisesti kuin psyykkisesti. Hevosyrittäjyys on työvoimavaltaista, ja yrittäjien jaksamiseen tulisikin kiinnittää huomiota. Yritystä pyöritetään yleensä yksin $63 \%$ kyselyyn vastaajista toimi ilman palkattua työvoimaa. Työn organisointiin, tekniikan hyödyntämiseen, sijaisapu- ja lomituspalveluihin ja muihin jaksamista parantaviin toimenpiteisiin pitäisi hevosalalla panostaa. Yrittäjän tulisi puntaroida omat voimavaransa ja tietotaitonsa, ja hyödyntää ostopalveluita tarpeen mukaan. Useimmiten hevosyrittäjillä on hevostaito hallussaan, mutta yrityksen liiketalouden hallinta kaipaa tukea. Yrittäjien liiketalousosaamiseen tarvitaan koulutusta.

Hevosyrittäjät näkivät tulevaisuuden pääosin positiivisena talouden taantumasta huolimatta. Kannattavuusnäkymiä pidettiin tyydyttävinä, jopa hyvinä. Kaikissa toimintamuodoissa uskottiin enemmän kysynnän kasvuun kuin vähenemiseen. Eniten kysyntää näyttäisi olevan palveluntuotannossa: ratsastustuntitoiminnassa, karsinapaikkojen vuokrauksessa ja ravihevosten valmennuspalveluissa. Tulevaisuuden mahdollisuuksia voivat olla entistä erikoistuneemmat palvelut, kuten terapiatoiminta ja "green care"-tyyppinen palvelutoiminta. Ravihevosten valmentajille kimppaomistajuuden ja uusien, kokemattomien hevosenomistajien yleistyminen tuovat uudenlaisia vaatimuksia asiakaspalveluun ja palvelumalleihin, olivatpa ne sitten internet-pohjaisia tietokanavia tai omistajajoukon ja valmentajan yhteisiä kahvituokioita.

Yrittäjän arkeen vaikuttaa myös muuttunut lainsäädäntö. Vuonna 2014 kaikkien tallien on täytettävä eläinsuojelusäädösten määrittämät vaatimukset $\mathrm{mm}$. eläinsuojien sisäkorkeudesta ja karsinakoosta. Samaan aikaan umpeutuu siirtymäaika talousvesiasetuksesta, joka koskettaa kiinteistöjen jätevesijärjestelmiä. Kyselyn mukaan tieto lainsäädännön vaatimuksista on tavoittanut hevosyrittäjät suhteellisen hyvin. Puolet vastaajista ilmoitti, että kyseisten säädösten sisällöt ovat vaikuttaneet investointipäätöksiin ja yritysten toimintaan. Koulutusta, opastusta ja tiedon levittämistä tullaan kuitenkin tarvitsemaan jatkossa yhä enemmän tallirakentamisen ja investointien suunnittelun tueksi.

Vaikka kyselyn tulokset henkivät hevosyrittäjien positiivisuutta ja uskoa tulevaisuuteen, tarvitaan edelleen toimenpiteitä yritystoiminnan kehittämiseksi sekä lisää tietoa hevosyrittäjyydestä, jotta se säilyy tulevaisuudessakin yhtenä maaseudun kasvavana elinkeinona.

\section{Kirjallisuus}

Heiskanen, M.-L., Klemola, I., Kumpulainen, M. \& Kauppinen, P. 2002. Hevostalous - merkitys ja tulevaisuus Suomessa. Hevostietokeskus. 84s.

Liljenstolpe, C. 2009. The Horse Industry in Europe of Today. Seminaariesitelmä 29.10.2009. EU Equus 2009 The Future Horse industry in Rural Areas and Society-seminaari Uppsala.

Matkailun edistämiskeskus MEK 2009. Kansallinen hevosmatkailututkimus 2009. MEK A:165. Helsinki.

Pussinen, S., Korhonen, J., Pölönen, I. \& Varkia, R. 2007. Kasvava hevosala - Hevosalan kehitysnäkymiä Suomessa. Laurea-ammattikorkeakoulun julkaisusarja B19. 91 s.

Suomen Yrittäjät 2008. Suomen Yrittäjien jäsentilastoja. http://www.yrittajat.fi/File/6a4c55bd-258e-49dfbd57-980d6b08a5d5/SYtilastot_09.pdf

Tiilikainen, S. 2004. Hevostalous maatiloilla. MTT:n selvityksiä 67. MTT:n Taloustutkimus.Helsinki.

Tike 2008. Maatilojen lukumäärä tuotantosuunnan mukaan työvoima- ja elinkeinokeskuksittain 2008. Matildatietopalvelu. Maa- ja metsätalousministeriön tietopalvelukeskus. http://www.matilda.fi

Tike 2009. Maatilarekisterin tiedot vuodelta 2008 löytyvät nyt Matildasta. Tiken tiedote 16.2.2009. Maa- ja metsätalousministeriön tietopalvelukeskus. http://www.mmmtike.fi/fi/index/tiedotteet/090213_maatilarekisteri.html 